\title{
PERLINDUNGAN HUKUM BAGI PEMULIA TANAMAN
}

\section{TITIN TITAWATI'), ALINE FEBRYANI LOILEWEN ${ }^{2)}$, GEDE TUSAN ARDIKA ${ }^{3)}$ \\ Program Studi Hukum Kampus Mataram UNMAS Denpasar}

\author{
e-mail,; titintitawati@gmail.com, ${ }^{2) .}$ alinefebriyani@gmail.com, ${ }^{3)}$ gedetusan @gmail.com
}

\begin{abstract}
ABSTRAK
Penelitian ini bertujuan untuk mengkaji dan menganalisis perlindungan hukum bagi pemulia tanaman dan penegakan hukum Perlindungan Varietas Tanaman (PVT). Penelitian ini merupakan penelitian hukum normative, yaitu penelitian yang didasarkan pada peraturan perundang-undangan yang tertulis dan berbagai literature yang berhubungan dengan permasalahan ini. Bentuk perlindungan hukum bagi pemulia tanaman adalah Undang-Undang Nomor. 29 tahun 2000 tentang Perlindungan Varietas Tanaman, telah memberikan perlindungan hukum bagi pemulia tanaman, melalui UU No. 12 Tahun 1992 Tentang Sistem Budidaya Tanaman (UUSBT) dan UU No. 29 Tahun 2000 (UUPVT), UUPVT memberikan perlindungan terhadap hak ekonomi pemulia, sedangkan UUSBT memberikan perlindungan hak moral pemulia.

Penegakan hukum terhadap pelanggaran PVT sudah dilakukan dengan baik, hal ini dibuktikan dengan beberapa kasus yang diajukan ke Pengadilan , namun masih ada beberapa kasus yang salah dalam penerapan hukumnya. Diharapkan pelaksanaan Peraturan PerUndangan-Undangan PVT lebih optimal.
\end{abstract}

Kata kunci; Perlindungan hukum, Pemulia Tanaman,

\section{ABSTRACT}

This study aims to study and to analyze the legal protection for plant breeders and law enforcement for Plant Variety Protection (PVP). This research is a normative legal research, which is based on written legislation and various literatures related to this issue. The form of legal protection for plant breeders is Law Number. 29 of year 2000 concerning Protection of Plant Varieties, has provided legal protection for plant breeders, through Law No. 12 of year 1992 concerning the Plant Cultivation System (UUSBT) and Law No. 29 of year 2000 (UUPVT), UUPVT provides protection for breeders 'economic rights, while UUSBT provides protection for breeders' moral rights. Law enforcement against violations of $P V P$ has been done well, this is evidenced by several cases submitted to the Court, but there are still some cases that are wrong in the application of the law. It is expected that the implementation of the PVP Invitation Act is more optimal.

Keywords; Plant Breeders, UUPVT, UUSBT.

\section{PENDAHULUAN}

\section{Latar Belakang}

Indonesia merupakan saah satu negara yang memiliki sumber daya hayati yang sangat beragam. Keaneka ragaman hayati ini merupakan sumber plasma nuftah dan dapat dmanfaatkan untuk mengembangkan varietas unggul di masa depan yang sangat penting untuk mendukung pembangunan ekonomi bidang pertanian pada khususnya dan pembangunan nasional pada umumnya.

Varietas tanaman merupakan salah satu faktor penunjang pembangunan ekonomi di bidang pertanian, tetapi masih banyak varietas tanaman di Indonesia yang belum jelas perlindungan hukumnya. Hal itu kemungkinan disebabkan antara lain oleh; a). pemulianya sendiri tidak mau meminta perlindungan, b) masih 
banyak yang belum mengetahui tentang Perlindugan Varietas Tanaman, c)varietas tanaman yang dihasilkan pemulia tidak memiliki nilai komersial sehingga tidak layak dilindungi.

Pada dasarnya ketentuan berupa undang-undang merupakan sarana yang diperlukan untukmendorong dan melindungi kegiatan dalam menghasilkan varietas tanaman yang bersifat unggul. Para pihak yang bergerak dalam bidang pemuliaan tanaman membutuhkan suatu aturan khusus yang dapat memberikan jaminan dan perlindungan hukum secara jelas dan tegas. Perlindungan yang di maksud berupa adanya pengakuan hak atas kekayaan intelektual bagi hasil invensi berupa varietas baru tanaman.

Perlindungan hukum pada hakekatnya sekaligus merupakan pelaksanaan dari berbagai kewajiban internasional yang harus dilakukan oleh Indonesia, khususnya yang berkaitan dengan Konvensi Perserikatan Bangsa-Bangsa tentang Keanekaragaman Hayati (United Nations Convention on Biological Diversity), Konvensi Internasional tentang Perlindungan Varietas Baru Tanaman (International Convention for the Protection of New Varietas of Plants), dan world Trade Organization/Trade Related Aspects of Intellectual Property rights yang antara lain mewajibkan kepada negara anggota seperti Indonesia mempunyai dan melaksanakan peraturan perundang-undangan di bidang Hak atas Kekayaan Intelektual (HKI).

Salah satu dari kewajiban yang harus ditaati Indonesia yang berkaitan dengan hak kekayaan intelektual (HKI) mensyaratkan; Satu, negara anggota untuk memberikan perlindungan terhadap varietas tanaman yang baru; Kedua, untuk mengembangkan penemuan-penemuan baru di bidang pertanian dan menggunakan dengan sebaik-baiknya kekayaan sumber daya hayati yang dimiliki Indonesia untuk merakit varietas unggul guna mendukung pembangunan ekonomi; Ketiga, untuk mendorong kegiatan yang menghasilkan varietas tanaman unggul dengan memberikan penghargaan bagi mereka (badan usaha atau orang) yang bergerak dibidang pemuliaan tanaman dan Keempat, untuk mendorong dan memberi peluang dunia usaha dalam pembangunan di dibidang pertanian, memberikan landasan hukum bagi upaya terciptanya varietas unggul yang baru dan pengembangan industri perbenihan.

Oleh karena itu, dalam rangka mendukung kegiatan pemuliaan tanaman dan memberikan situasi kondusif bagi perkembangan industri perbenihan nasional, maka pada tanggal 20 Desember Tahun 2000 telah disahkan Undang-Undang Nomor 29 Tahun 2000 tentang Perlindungan Varietas Tanaman (UU PVT). Berdasarkan Pasal 1.1 UU PVT dikatakan bahwa Perlindungan varietas tanaman selanjutnya disingkat PVT, adalah Perlindungan khusus yang diberikan negara, yang dalam hal ini diwakili oleh Pemerintah dan pelaksanaannya dilakukan oleh Kantor Perlindungan Varietas Tanaman, terhadap varietas tanaman yang dihasilkan oleh pemulia tanaman melalui kegiatan pemulia tanaman. Perlindungan semacam itu akan mendorong semangat dan kreativitas di bidang pemuliaan tanaman, sehingga dapat dihasilkan penemuan berbagai varietas unggul yang sangat diperlukan masyarakat.

Konsep Perlindungan Varietas Tanaman (PVT) ini dikembangkan karena ketentuan tentang paten tidak memberikan perlindungan atas varietas tanaman baru sebagai hasil dari proses permuliaan tanaman. Berdasarkan ketentuan internasional tentang HKI dikatakan bahwa jika negara tidak memberikan PVT dalam UU paten, maka negara tersebut harus membuat undang-undang khusus tersendiri yang efektif untuk perlindungan varietas tanaman baru ini. Hukum tentang paten Indonesia hanya melindungi proses untuk membuat atau memproduksi tanaman dengan menggunakan teknik-teknik bioteknologi. Sedangkan PVT memberikan perlindungan atas produk, yang berupa bibit/benih yang dihasilkan dari teknik-teknik bioteknologi maupun alami dalam bentuk varietas tanaman baru, persyaratan perlindungan dan perkecualian. Oleh karena itu Varietas tanaman yang tidak dilindungi dalam paten dapat dilindungi dalam UU PVT.

Perlindungan varietas tanaman (PVT) yang merupakan "sui generis" dari paten merupakan perlindungan terhadap varietas tanaman yang dihasilkan oleh pemuliatanaman yang mengandung unsur baru, unik, seragam, stabil (BUSS). Di Indonesiapengelolaan Paten dan pengelolaan PVT tidak berada di satu tangan, Paten berada dibawah Kementerian Hukum dan HAM Republik Indonesia, sedangkan PVT dikelola dibawah Kementerian Pertanian Republik Indonesia. Dengan adanya Undang-UndangNomor 29 Tahun 2000 tentang Perlindungan Varietas Tanaman, maka keberadaan pemulia yang melakukan pemuliaan akan terlindungi, dimana pemulia yang menghasilkan varietas tanaman yang memenuhi ketentuan UU PVT tersebut dapat memperoleh hak PVT dan mendapatkan manfaat ekonomi dari hasil pemuliaannya itu.

\section{Rumusan Masalah}

1. Apakah Undang-Undang Nomor 29 Tahun 2000 tentang Perlindungan Varietas Tanaman telah cukup melindungi pemulia tanaman?

2. Bagaimanakah penegakan hukum mengenai varietas tanaman? 


\section{Tujuan Penelitian}

Penelitian ini bertujuan untuk mengkaji dan menganalisis bagaimana perlindungan hukum bagi pemulia tanaman dan penegakan hukum terhadap varietas tanaman.

\section{METODE PENELITIAN}

Penelitien ini menggunakan bentuk penelitian normative yaitu penelitian yang didasarkan pada peraturan perUndang Undangan tertulis dan berbagai literatur yang berhubungan dengan permaslahan yang akan dibahas dalam penelitian ini.

Sumber-sumber penelitian hukum dapat debedakan menjadi sumber penelitian yang berupa bahanbahan hukum primer yang terdiri dari peraturan perUndang-Undangandan putusan-putusan Hakim, sedangkan bahan sekunder berupa semua publikasi yang bukan meruopakan dokumentasi resmi, publikasi tentang hukum, buku-buku teks, kamus hukum, jurnal hukum dan komentar-komentar hukum.

Bahan -bahan hukum yang diperoleh lewat penelitian kepustakaan yang meliputi bahan hukum primer, bahan hukum sekunder dan bahan hukum tersier. Bahan hukum yang diperlukan kemudian diinventarisasi kemudian bahan hukum yang berkenaan dengan pokok masalah atau tema sentral diidentifikasi untuk digunakan sebagai bahan analisa yang dilakukan pada awal penelitian dan juga selama penelitian ini berlangsung sehingga didapatkan suatu kesimpulan dan saran yang bermanfaat untuk hasil penelitan. Di dalam penelitian hukum normative, analisa terhadap asas-asas hukum dilakukan terhadap kaidah hukum , norma, dan peraturan perUndang-Undangan yang berlaku.

\section{PEMBAHASAN}

\section{Perlindungan Hukum bagi Pemulia Tanaman menurut Undang-Undang Nomor.29 Tahun 2000 tentang Perlindungan Varietas Tanaman (UU PVT).}

Hak Kekayaan Intelektual atau disingkat "HKI" adalah hak yang timbul atas hasil olah pikir manusia yang menghasilkan suatu produk atau proses yang berguna untuk manusia. Secara umum dapat dikatakan bahwa objek yang diatur dalam HKI adalah karya-karya yang lahir karena kemampuan intelektual manusia. Ada yang berpendapat bahwa hak-haktersebut digolongkan ke dalam hak-hak atas barang-barang tak berwujud atau intangible.Jika ide-ide tersebut keluar dari pikiran manusia dan menjelma dalam suatu bentuk kesusteraan, ilmu pengetahuan dan lain-lain, maka menjadi benda berwujud (tangible) dan dapat menjadi sumber keuntungan.

Digolongkannya hak-hak tersebut ke dalam hukum kebendaan adalah karena hak-hak tersebut memiliki sifat-sifat kebendaan dan dapat dimiliki secara absolute (hak mutlak). Ciri utamanya adalah hakhak tersebut dapat dijual, dilisensikan, diwariskan dan lain-lain layaknya hak kebendaan lainnya. Hak-hak tersebut dapat dipindah tangankan kepemilikannya berdasarkan alasan yang sah yang dibenarkan oleh peraturan perUndang-Undangan.

Dari sinilah ciri khas HKI sebagai hak privat (private rights), sehingga seseorang bebas untuk mengajukan permohonan atau mendaftarkan karya intektualnya atau tidak. Hak ekslusif yang diberikan Negara kepada individu pelaku HKI (inventor, pencipta, pendesain dan sebagainya) adalah sebagai penghargaan atas hasil karya atau kreativitasnya dan agar orang lain termotivasi untuk mengembangkannya lagi lebih lanjut.

HKI merupakan salah satu bidang yang dapat memberikan manfaat dalam pembangunan ekonomi suatu Negara, oleh karena itu untuk dapat mengoptimalkan fungsi HKI dalam pertumbuhan ekonomi salah satu cara adalah dengan member perlindungan terhadap HKI. Perlindungan diperlukan untuk menjamin bahwa hak ekslusif kekayaan intelektual seseorang tidak dirugikan oleh pihak lain, sehingga dengan adanya perlindungan dapat menciptakan iklim persaingan yang sehat dan mendorong pemilik HKI untuk menginvestasikan dan mengalihkan teknologinya.

UU PVT yang disusun sebagai usaha untuk lebih meningkatkan minat dan peran serta perorangan maupun badan hukum untuk melakukan kegiatan pemuliaan tanaman dalam rangka meningkatkan varietasunggul baru. Konsep penghargaan dan perlindungan hukum yang terdapat didalam UU PVT ini 
meliputi pemberian perlindungan hukum atas kekayaan intelektual dalam menghasilkan varietas tanaman, termasuk didalamnya hak untukmenikmati manfaat ekonomi dan hak-hak lainnya.

Perlindungan terhadap hak atas varietas baru tanaman untuk menikmati manfaat ekonomi atas varietas temuannya merupakan salah satu wujud dar ipenghargaan dan pengakuan atas keberhasilan pemulia dalam menemukan atau mengembangkan varietas tanaman baru. Perlindungan ini tidak terdapat di dalam perundang-undangan sebelum berlakunya UU PVT.

Hak Ekonomi ini merupakan bentuk penghargaan yang diatur dalam UU PVT yang diberikan kepada pemulia yang telah melakukan kegiatan pemuliaan, dan hak PVT ini bersifat eksklusif. Penghargaan dalam bentuk hak eksklusif untuk menikmati manfaat ekonomi ini sejalan dengan "reward theory" dan recovery theory". Namun, sifat eksklusif dalam hak pemulia tidak bersifat penuh karena ada pembatasan yang mengandung fungsi sosial seperti yang diatur di dalam Pasal 10 Ayat 1 UU PVT.

Ketentuan Pasal 10 Ayat 1 UU PVT menyebutkan bahwa:

a. Penggunaan sebagian hasil panen dari varietas yang dilindungi, sepanjang tidak untuk tujuan komersial.

b. Penggunaan varietas yang dilindungi untuk kegiatan penelitian, pemuliaan

tanaan, dan perakitan varietas baru

c. Penggunaan oleh pemerintah atas varietas yang dilindungi dalam rangka kebijakan pengadaan pangan dan obat-obatan dengan memperhatikan hak-hak ekonomi dari pemegang hak PVT. Penjelasan umum UU PVT juga menyebutkan bahwa "....Dalam pelaksanaannya undang-undang ini dilandasi dengan prinsip-prinsip dasarnyang mempertemukan keseimbangan kepentingan umum dan pemegang hak PVY". UU PVT yang memberikan perlindungan hukum bagi pemulia untuk menikmati manfaat ekonomi dan hak-hak lainnya yang dimiliki pemulia, diharapkan dapat mendorong kreativitas di bidang pemuliaan tanaman, sehingga dapat dihasilkan berbagai penemuan varietas unggul bermutu yang mendukung industri perbenihan modern.

Perlindungan hukum terhadap hak untuk menikmati manfaat ekonomi tersebut sejalan dengan "incentive theory". Teori ini mengaitkan pemberian insentif bagi para penemu varietas tanaman, yang bertujuan untuk memacunya kegiatan-kegiatan penelitian yang berguna bagi perkembangan varietas unggul. Perbedaan mendasar antara Undang-Undang Nomor 12 Tahun 1992 tentang Sistem Budidaya Tanaman dan Undang-Undang Nomor 29 Tahun 2000 tentang Perlindungan Varietas Tanaman adalah perlindungan terhadap hak ekonomi yang dimiliki oleh pemulia. Undang-Undang Nomor 12 Tahun 1992 tentang Sistem Budidaya Tanaman tidak memberikan perlindungan terhadap hak

ekonomi yang dimiliki pemulia, tetapi memberikan perlindungan terhadap hak moral pemulia. Sedangkan UU PVT disusun sebagai usaha untuk memberikan perlindungan hukum atas kekayaan intelektual pemulia dalam menghasilkan varietas tanaman, termasuk didalamnya hak pemulia untuk menikmati manfaat ekonomi dan hak-hak lainnya.

Pengaturan hukum yang terkait dengan perlindungan terhadap hak yang dimiliki oleh pemulia ini, selain dalam Pasal 55 Undang-Undang Nomor 12 Tahun 1992 tentang Sistem Budidaya Tanaman, dapat juga terdapat dalam ketentuan Pasal 4, 6, 8 dan 42 UU PVT. Ketentuan Pasal 4 Ayat 1 UU PVT mengatur mengenai jangka waktu perlindungan yang diberikan kepada pemulia atas varietas tanaman hasil temuannya. Jangka waktu perlindungan ini dibedakan menjadi 2(dua) kategori, yaitu kategori tanaman semusim dan tanaman tahunan. Tanaman semusim mendapatkan perlindungan hak PVT selama 20 tahun, tanaman yang dikategorikan sebagai tanaman semusim ini contohnya tanaman padi, tebu, tembakau, kapas, kentang, jamur, jagung dan sebagainya. Sementara untuk tanaman tahunan mendapat perlindungan hak PVT selama 25 tahun, tanaman yang dikategorikan sebagai tanaman tahunan ini contohnya jati, kelapa sawit, karet, mangga, sagu dan sebagainya.

Pembentukan UU PVT ini banyak mengadopsi International Convention for The Protection of New Varieties of Plants (selanjutnya disebut UPOV Convention), yaitu suatu ketentuan internasional yang khusus memberikan perlindungan bagi varietas baru tanaman yang di bentuk untuk melindungi hak pemulia (breader's rights). Hak pemulia (breeder's rights) merupakan hak ekslusif yang diberikan kepada pemegangnya untuk menghasilkan atau menggunakan kembali dan menjual varietas tanaman yang telah dihasilkan.10 Dalam UU PVT diberikan suatu hak khusus yang dimaksudkan untuk menegaskan pengakuan atas adanya hak yang dimiliki oleh pemilik/pemegang hak, yaitu hak untuk melarang atau memberi ijin penggunaan secara komersial dari hak pemulia tersebut. Hak yang di maksud adalah Hak Perlindungan Varietas Tanaman (Hak PVT). Baik UPOV Convention maupun UU PVT mengatur bahwa tidak semua invensi varietas baru tanaman dapat begitu saja mendapatkan perlindungan hak pemulia. Hal ini

disebabkan karena varietas tanaman yang dapat diberikan perlindungan (PVT) merupakan varietas dari jenis atau spesies tanaman baru, unik, seragam, stabil dan di beri nama. 
Selain itu adanya pengaturan secara khusus mengenai perlindungan terhadap varietas tanaman ini akan meningkatkan minat dan peran serta serta baik secara perorangan maupun badan hukum untuk melakukan kegiatan pemuliaan tanaman dalam rangka menghasilkan varietas tanaman baru yang unggul, karena para pemulia atau pemegang hak perlindungan terhadap varietas tanaman akan memiliki hal tertentu yang memiliki perlindungan hukum secara memadai.

\section{Penegakan Hukum Perlindungan Varietas Tanaman.}

PVT diberikan kepada varietas dari jenis atau spesies tanaman yang baru, unik, seragam, stabil, dan diberi nama. Suatu varietas dianggap baru apabila pada saat penerimaan permohonan hak PVT, bahan perbanyakan atau hasil panen dari varietas tersebut belum pernah diperdagangkan di Indonesia. Boleh juga sudah diperdagangkan, asal tidak lebih dari setahun. Jika diperdagangkan di luar negeri, maka tidak boleh lebih dari empat tahun untuk tanaman semusim dan enam tahun untuk tanaman tahunan. Sedangkan kriteria varietas dianggap unik apabila varietas tersebut dapat dibedakan secara jelas dengan varietas lain yang keberadaannya sudah diketahui secara umum pada saat penerimaan permohonan hak PVT. Varietas dianggap seragam apabila sifat-sifat utama atau penting pada varietas tersebut terbukti seragam meskipun bervariasi sebagai akibat dari cara tanam dan lingkungan yang berbeda-beda. Suatu varietas dianggap stabil apabila sifat-sifatnya tidak mengalami perubahan setelah ditanam berulang-ulang, atau untuk yang diperbanyak melalui siklus perbanyakan khusus, tidak mengalami perubahan pada setiap akhir siklus tersebut.

Varietas yang apabila diperbanyak tidak mengalami perubahan adalah varietas yang tetap stabil di dalam proses perbanyakan benih atau propagasi dengan metode tertentu, misalnya produksi benih hibrida, kultur jaringan, dan stek.

Varietas yang dapat diberi PVT harus diberi penamaan yang selanjutnya menjadi nama varietas yang bersangkutan, dengan ketentuan:

1. Nama varietas tersebut terus dapat digunakan meskipun masa perlindungannya telah habis

2. Pemberian nama tidak boleh menimbulkan kerancuan terhadap sifatsifat varietas.

3. Penamaan varietas dilakukan oleh pemohon hak PVT dan didaftarkan pada Kantor PVT.

4. Apabila penamaan tidak sesuai dengan ketentuan butir b, maka Kantor PVT berhak menolak penamaan tersebut dan meminta penamaan baru.

5. Apabila nama varietas tersebut telah dipergunakan untuk varietas lain, maka pemohon wajib mengganti nama varietas tersebut.

6. Nama varietas yang diajukan dapat juga diajukan sebagai merekdagang sesuai dengan peraturan perundang-undangan yang berlaku.

Pengembangan varietas tanaman baru dapat dilakukan melalui 2 cara yakni melalui pemuliaan tanaman klasik dan melalui bioteknologi, misal rekayasa genetika. Varietas tanaman yang dihasilkan dari rekayasa genetika dilindungi dengan PVT, namun proses/metode untuk menghasilkan varietas baru dapat dilindungi dengan paten, sepanjang persyaratan dipenuhi. Seandainya diinginkan perlindungan ganda tersebut, maka kriteria untuk memenuhi paten harus diprioritaskan, karena kriteria kebaruan (novelty) pada paten lebih sulit untuk dicapai dibandingkan pada PVT. Bahkan suatu metode pemuliaan, apabila memiliki nilai ekonomi, masih bersifat rahasia dan dilakukan upaya menjaga kerahasiaan, apabila diinginkan, dapat pula dilindungi dengan rezim rahasia dagang.

Pasal 7 Undang-Undang PVT menyebutkan, varietas lokal milik masyarakat dikuasai oleh Negara. Penguasaan oleh Negara dilaksanakan oleh Pemerintah dan diatur lebih lanjut dengan Peraturan Pemerintah. Tidak seperti rezim HKI lainnya yang permohonannya diajukan kepada Ditjen HKI Departemen Hukum dan HAM, hak PVn Hukum dan HAM, hak PVT dimintakan perlindungannya melalui pendaftaran kepada Departemen Pertanian.

Hak yang diperoleh Pemegang PVT adalah hak untuk menggunakan dan memberikan persetujuan kepada orang atau badan hukum lain untuk menggunakan varietas berupa benih dan hasil panen yang digunakan untuk propagasi. Ketentuan ini berlaku juga untuk varietas turunan esensial yang berasal dari suatu varietas yang dilindungi atau varietas yang telah terdaftar dan diberi nama, varietas yang tidak dapat dibedakan secara jelas dari varietas yang dilindungi, dan varietas yang diproduksi dengan selalu menggunakan varietas yang dilindungi.

Hak untuk menggunakan varietas sebagaimana yang dimaksud pada ayat (1) meliputi kegiatan:

a. memproduksi atau memperbanyak benih; b. menyiapkan untuk tujuan propagasi; c. mengiklankan; d. menawarkan; e. menjual atau memperdagangkan; f. mengekspor; g. mengimpor; h. mencadangkan untuk keperluan sebagaimana dimaksud dalam butir a, b, c, d, e, f, dan g. 
Pasal 5 UU PVT menetapkan jika suatu varietas dihasilkan berdasarkan perjanjian kerja, maka pihak yang memberi pekerjaan itu adalah pemegang hak PVT, kecuali diperjanjikan lain antara kedua pihak dengan tidak mengurangi hak pemulia. Jika suatu varietas dihasilkan berdasarkan pesanan, maka pihak yang memberi pesanan itu menjadi pemegang hak PVT, kecuali diperjanjikan lain antara kedua pihak dengan tidak mengurangi hak pemulia.

Jangka waktu perlindungan yang diberikan selama 20 (dua puluh) tahun untuk tanaman semusim, dan 25 (dua puluh lima) tahun untuk tanaman tahunan. Sanksi yang dapat diterapkan atas pelanggaran hak PVT adalah pidana penjara paling lama 7 (tujuh) tahun dan denda paling banyak Rp 2.500.000.000,00 (dua miliar lima ratus juta rupiah).

Penerapan PVT di lapangan semestinya mengandung klausul jika aspek hukum PVT berhadapan dengan kasus khusus. Ini diperlukan lantaran demikian beragamnya tingkat pendidikan dan pengetahuan hukum yang bersifat menyeluruh. Contoh kasus pelanggaran PVT yang cukup menggemparkan dunia perbenihan Indonesia terjadi di sebuah desa yang terpencil. Seorang petani yang gemar berinovasi dan tinggal di desa mencoba menyilangkan benih tanaman yang sudah memiliki hak paten dengan benih lokal lain yang tumbuh di desanya. Setelah melakukan aneka penyilangan selama bertahun-tahun, akhirnya ia berhasil menghasilkan benih baru yang jauh lebih baik daripada benih bermerek dan sudah dilindungi hukum tersebut.

Sesuai sifat masyarakat desa, keberhasilan itu langsung ditiru oleh masyarakat sekitar. Petani yang gemar berinovasi itupun menjual benih temuannya dengan harga lebih murah dari pada benih bermerek dan terlindung hukum itu. Perusahaan benih bermerek itu mengamati meluasnya benih baru dan kemudian mengujinya ke lembaga penelitian resmi. Hasilnya, benih ciptaan sang petani masih mengandung genetik yang mirip dengan benih berpaten, meskipun hasilnya memang lebih bagus. Petani yang gemar berinovasi itupun diajukan ke pengadilan dan keputusan hakim: sang petani bersalah. Kasus ini menimbulkan prokontra karena keberanian petani berinovasi adalah suatu hal yang justru perlu didukung. Kemudahan dan keberanian berinovasi di masyarakat desa jarang terjadi. Namun, keberanian tersebut terbukti terbentur pada hukum formal yang sudah ada.

Kasus penegakan hukum lain yang menarik ialah perseteruan antara dua badan hukum yang samasama memproduksi benih. Pengadilan Negeri Jember menghukum salah satu perusahaan dengan hukuman ganti rugi sebesar Rp5-miliar kepada lawannya, produsenbenih lain. Hukuman tambahan lain ialah memasang iklan permohonan maaf di lima media besar di Indonesia.Terhukum dituduh telah melakukan perbuatan pelanggaran hukum tentang sistem budidaya tanaman serta perlindungan varietas tanaman. Sebagaimana diatur di UU No 12/92 tentang sistem budidaya tanaman dan UU No 29/2000 tentang perlindungan varietas tanaman. Pada amar putusan ditegaskan, pelanggaran yang terjadi bisa dikaitkan dengan pelanggaran hak cipta atau hak atas kekayaan intelektual dari sebuah lembaga riset untuk memperoleh benih unggul sayuran dan hortikultura.

\section{SIMPULAN DAN SARAN}

\section{Simpulan}

1. Undang-Undang Nomor. 29 tahun 2000 tentang Perlindungan Varietas Tanaman, telah memberikan perlindungan hukum bagi pemulia tanaman, melalui UU No. 12 Tahun 1992 Tentang Sistem Budidaya Tanaman (UUSBT) dan UU No. 29 Tahun 2000 (UUPVT), UUPVT memberikan perlindungan terhadap hak ekonomi pemulia, sedangkan UUSBT memberikan perlindungan hak moral pemulia.

2. Penegakan hukum terhadap pelanggaran PVT sudah dilakukan dengan baik, hal ini dibuktikan dengan beberapa kasus yang diajukan ke Pengadilan, namun masih ada beberapa kasus yang salah dalam penerapan hukumnya.

\section{Saran}

Diharapkan pelaksanaan Peraturan PerUndangan-Undangan PVT lebih optimal. 


\section{DAFTAR PUSTAKA}

\section{Buku Literatur}

Adami Chazawi, 2001. Tindak Pidan Hak Atas Kekayaan Intelektual. Raja Grafindo Persada, Jakarta.

Andriana Krisnawati dan Saleh Gazalba, 2004. Perlindungan Hukum Varietas Baru Tanaman Dalam Persfektif Hak Paten dan Hak Pemulia. PT. Raja Grafindo Persada, Jakarta.

Endang Purwaningsih Dkk, 2019, Hak Kekayaan Intelektual dan Investasi, Intrans Publishing, Malang Jawa Timur.

Muhammad Djumhana dan R Djubaedillah, 2003. Hak Milik Intelektual, Sejarah Teori dan Praktiknya di Indonesia, Citra Aditya Bhakti, Bandung.

Nina Nurani,2007. Perlindungan Hak Milik IntelektualVarietas Tanaman (Guna Peningkatan Daya Saing Agribisnis. Citra Adtya Bhakti, Bandung.

\section{PerUndang-Undangan}

Undang-Undang Nomor 12 Tahun 1992 Tentang Sistem Budidaya Tanaman.

Undang-Undang Nomor. 29 Tahun 2000 Tentang Perlindungan Varietas Tanaman.

\section{Internet}

Http//www.bphn.go.id.data.pdf, diakses pada Tanggal 3 Februari 2020

Pvtpp.setjen.pertanian.go.id, diakses pada tanggal 4 Februari 2020.

http//www.hukumonline.com/berita/hol 11250/perlindungan hukum varietas tanaman, diakses pada tanggal 2 februri 2020.

Perlindungan Hukum Varietas Tanaman, Siapa Perduli.hukumonline.com.html, diakses pada tanggal 4 Februari 2020. 